UDK 631.44

\title{
THE SOIL COVER STRUCTURE AND ELEMENTARY SOIL AREAS OF THE OPILLIA
}

\author{
Taras Yamelynets, Mykola Fedotikov
}

\author{
Ivan Franko National University of Lviv, \\ P. Doroshenko St., 41, UA-79007 Lviv, Ukraine, \\ e-mail: taras.yamelynets@gmail.com
}

For studying the soil cover structure of Opillia region, we used methods for the identification (natural-cartometric, relief sculpture, quality-genetic) and interpretation (statistical cartometric, functional and analytical) of the soil cover structure. The natural-cartometric method was used to characterize elementary soil areas of the key area, what makes it possible to determine the parameters of the soil structure and obtain quantitative indicators for the key elementary soil areas parameters, which are: elementary soil areas composition and area ratio, complexity, fractionality, breakdown, contrast ratio and heterogeneity.

This article is devoted to the study results of qualitative and quantitative characteristics of elementary soil areas of the Opillia within Khodorivsko-Buchatskyi region, hereinafter KhodorivskoBuchatske Opillia. With coefficient of the differentiation of the soil outlines and methods of variation statistics were identified and analyzed the degree of variability ESA areas. The degree of tortuosity and elongation of area limits using the coefficient of the dismemberment were studied. Investigated the character of outlines of elementary soil areals within the area of research. Identified the basic features of ESA borders depending on various environmental factors. The certain laws of changing of the basic parameters of elementary soil areas, which form the soil structure of KhodorivskoBuchatske Opillia were determined and described in the article.

Key words: elemental soil areal (ESA), soil structure (SS), coefficient of the differentiation of the soil outlines (CDSO), coefficient of dismemberment (CD), coefficient of variability (CV).

Soil cover is a complex system consisting of many elements, which, when interacting with each other on one and the same level and in a different manner, form a structure. To understand the nature of the soil cover, as a system, there is a need to explore that interconnected set of primary elements that form the system at the lowest level of the organization. These initial, primary, smallest units are elementary soil areals (hereinafter ESA). According to V. Friedland, each ESA can be characterized by the following features: geometry (or shape), content (i.e., the ratio of soil or soils that make it up to a certain classification unit), conditions under which ESA was formed and its place in the smallest integrated heterogeneous soil units, which are soil combinations, typical of it only [9].

(C) Yamelynets T., Fedotikov M., 2017 
In order to investigate the soil structure of certain territory, we need to analyze and organize all of its components, from the smallest ones, that is, ESA. And, as mentioned above, ESA is characterized by a number of traits that differ not only objectively, by definition, but also by the specifics of interpretation and analysis.

Professor V. Friedland developed a concept of the structure of the soil in the early 70 's of the 20th century. He wrote a monograph devoted entirely soil combinations and give a definition of soil structure (hereinafter SS) as the areals of certain soils manifoldly and rhythmically repeated in space that create a well-established structure and pattern of soil, and stable mechanisms of geochemical and geographical links between soils that are in this structure. Also, system approach (which had just become popular due to the introduction of mathematical research methods to the science) allowed V. Friedland to give definition of the soil structure smallest unit, i.e. elementary soil areal: soils belonging to any classification unit of the lowest rankig which occupy the space from all other sides limited by other elementary soils or non-soil formations [9].

Friedland's work was continued and supplemented by Prof. Y. Hodelman. Unlike Prof. Friedland, who used the SS term to refer to soil cover of any area only, Prof. Y. Hodelman believes that eventually there is another use of the word - to denote specific types of structures as taxonomic concept that involves regular alternation of a certain number of elementary units of soil characterized by common origin and development, certain geometric parameters and forming confined space areals. Each areal is offered to be referred to as elementary structural soil areal [2].

Different approaches of the soil mapping reflecting the structure of soil are considered in a large number of works. These are works by V. Friedland [8, 9], Y. Hodelman [2], N. Strohanova [7], L. Prasolov [4], O. Haskevych [1], V. Radzii [5, 6] S. Pozniak, Y. Krasieha, M. Kit [3] and many others. The mentioned above scientists have analyzed the impact of soil differentiation factors on the formation of the types of SS, investigated various methods of ESA identification and classification, submitted comments on the methods and ways of soil maps generalization, soil combinations etc.

The complex surveys of the soil structure for the Opillia region have not been carried out before. Characteristics of ESA of Opillia region is a necessary part of the research that will enable to pass to the higher level characteristic of the SS of the studied region - soil microcombinations and combinations.

Materials and methods. To analyze the genetic and morphological structure of the study area, materials of large-scale soil surveys in the scale of 1:10,000 by Ternopil branch of "Ukrzemproekt" in 1995, as well as medium and large-scale topographic maps were used. ESA was assumed to be the smallest area of soil, which in this scale can be marked on the map as a separate contour (lowest classification unit - type, kind). Also, medium- and small-scale soil maps, topographical maps and other maps of the studied territory were used in the work. According to research materials using ESRI's ArcGIS software package, a vector soil map and attribute tables were created with which measurements were made. The data obtained in ArcGIS was transferred to the the Microsoft Office Excel package, where they were further processed by the methods of variation statistics. 
ESA was assumed to be the smallest area of soil, which in this scale can be marked on the map as a separate contour (lowest classification unit - type, kind). In studying the soil structure of Khodorivske-Buchatske high plains, we used methods for the identification (naturalcartometric, relief sculpture, quality-genetic) and interpretation (statistical cartometric, functional and analytical) of the soil structure. We selected Olesha study area as model area within Khodorivske-Buchatske Opillia (Fig. 1). ESA analysis was provided within this model area, in particular, the natural-cartometric works on field clarification of the boundaries of some soil contours, primarily of eroded characteristics of background soils was conducted in 2015-2016.

We used the natural-cartometric method for description of the ESA of the key area, what makes it possible to determine the parameters of the soil structure and obtain quantitative indicators for the key ESA parameters, which are: ESA composition and area ratio, heterogeneity, contrast ratio, complexity, fractionality and breakdown.

Results. There are several dominant soils types in the area of investigation such as: grey forests, dark-grey podzolized and chernozems podzolized. The biggest amount of ESA (15) belongs to subtypes of type chernozems podzolized soils in the Olesha study area.

The type of grey forests soils in the study area is widespread in the western part of the area, there are 11 ESA, 185,32 hectares or $16,06 \%$ of the total area of the Olesha study area [Table 1]. The ESA of grey forests soils of the study area are not differentiated in granulometric composition, but differ at the lowest classification level - by erosion degree.

The type of dark-grey podzolized soils in the model area is represented by seven ESA that are located in the southwestern part of the country and occupy an area of 224,19 ha or $19.43 \%$ of the total model area [Table 1]. These areals, at the generic level, are represented by modal and eroded soils. Within model area, all areas of dark-grey podzolized soils are not differentiated in granulometric composition - they are medium-grained.

The dominant place in the soil cover structure of the territory of the Olesha study area is occupied by chernozems podzolized. The 15 ESA determined within model area, which occupy more than half of the area, or $54,79 \%$, and are distributed mainly in the east and north-east part of model area. These soils are represented by modal and eroded types of soils. Modal soil types cover an area of 257,1 hectares, which is about a quarter (22,29\%) of the total area of the Olesha study area [Table 1]. Chernozem podzolized is not differentiated by granulometric composition or rock type.

In addition to zonal soils, azonal soils are determined within the study area. In particular, the small areals of meadow-chernozem, chernozem-meadow, meadow-bog soils, which together occupy $9,71 \%$ of the model area [Table 1 ]. 
Table 1

The morphometric properties of ESA within Olesha model area, Khodorivsko-Buchatske Opillia

Морфометричні властивості ЕГА ключової ділянки “Олеша”, Ходорівсько-Бучацького Опілля

\begin{tabular}{|c|c|c|c|c|c|c|c|c|c|c|c|c|}
\hline \multirow[b]{2}{*}{ № } & \multirow[b]{2}{*}{ Full name of the soil } & \multirow{2}{*}{ 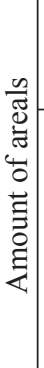 } & \multicolumn{5}{|c|}{ Area, hectares } & \multirow{2}{*}{$\begin{array}{l}\text { CDSO } \\
\text { (The } \\
\text { coeffi- } \\
\text { cient } \\
\text { of the } \\
\text { differen- } \\
\text { tiation } \\
\text { of the } \\
\text { soil } \\
\text { outlines) }\end{array}$} & \multicolumn{3}{|c|}{$\begin{array}{c}\text { CD (The } \\
\text { coefficient of the } \\
\text { dismemberment) }\end{array}$} & \multirow[b]{2}{*}{$\mathrm{CV}$} \\
\hline & & & 吾 & $\begin{array}{l}\frac{\pi}{5} \\
\stackrel{0}{0} \\
t_{0}^{\circ} \\
0^{\circ}\end{array}$ & 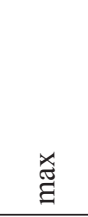 & . & 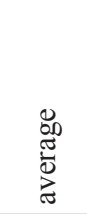 & & 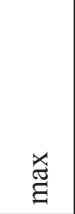 & 寻 & 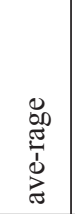 & \\
\hline 1 & 2 & 3 & 4 & 5 & 6 & 7 & 8 & 9 & 10 & 11 & 12 & 13 \\
\hline 1 & $\begin{array}{l}\text { Grey forests gleyish } \\
\text { middle coarse on } \\
\text { loess-like subclay }\end{array}$ & 3 & 64,69 & 5,61 & 45,45 & 5,63 & 21,56 & 0,74 & 2,08 & 1,22 & 1,67 & 0,98 \\
\hline 2 & $\begin{array}{l}\text { Grey forests gleyish } \\
\text { middle coarse } \\
\text { weakly washed (30- } \\
50 \% \text { ) on loess-like } \\
\text { subclay }\end{array}$ & 1 & 30,92 & 2,68 & 30,92 & 30,92 & 30,92 & - & - & - & - & - \\
\hline 3 & $\begin{array}{l}\text { Grey forests gley } \\
\text { middle coarse } \\
\text { weakly washed on } \\
\text { loess-like subclay }\end{array}$ & 3 & 42,98 & 3,73 & 21,23 & 4,91 & 14,33 & 0,44 & 2,1 & 1,29 & 1,75 & 0,59 \\
\hline 4 & $\begin{array}{l}\text { Grey forests gleyish } \\
\text { middle coarse } \\
\text { meanly washed (10- } \\
30 \%) \text { on loess-like } \\
\text { subclay }\end{array}$ & 4 & 46,73 & 4,05 & 21,86 & 4,74 & 11,68 & 0,5 & 1,44 & 1,3 & 1,39 & 0,66 \\
\hline 5 & $\begin{array}{l}\text { Dark-grey } \\
\text { podzolized gleyish } \\
\text { meanly coarse silty } \\
\text { clayey soils on } \\
\text { loess-like subclay } \\
\end{array}$ & 1 & 26,63 & 2,31 & 26,63 & 26,63 & 26,63 & - & - & - & - & - \\
\hline 6 & \begin{tabular}{|l} 
Dark-grey \\
podzolized gleyish \\
with spots of weakly \\
washed (30-50\%) \\
meanly coarse silty \\
clayey soils on \\
loess-like subclay \\
\end{tabular} & 2 & 125,58 & 10,89 & 95,8 & 29,77 & 62,79 & 0,53 & 3,79 & 1,83 & 2,81 & 0,74 \\
\hline 7 & $\begin{array}{l}\text { Dark-grey } \\
\text { podzolized gleyish } \\
\text { weakly washed } \\
\text { meanly coarse silty } \\
\text { clayey soils on } \\
\text { loess-like subclay } \\
\end{array}$ & 4 & 71,98 & 6,24 & 26,26 & 12,85 & 18 & 0,23 & 2,5 & 1,48 & 2,02 & 0,33 \\
\hline
\end{tabular}


End of table

\begin{tabular}{|c|c|c|c|c|c|c|c|c|c|c|c|c|}
\hline 1 & 2 & 3 & 4 & 5 & 6 & 7 & 8 & 9 & 10 & 11 & 12 & 13 \\
\hline 8 & $\begin{array}{l}\text { Chernozems } \\
\text { podzolized gleyish } \\
\text { meanly coarse silty } \\
\text { clayey soils on } \\
\text { loess-like subclay }\end{array}$ & 2 & 257,1 & 22,29 & 248,95 & 8,15 & 128,55 & 0,94 & 3,23 & 1,39 & 2,31 & 1,32 \\
\hline 9 & $\begin{array}{l}\text { Chernozems } \\
\text { podzolized gleyish } \\
\text { with spots of weakly } \\
\text { washed }(30-50 \%) \\
\text { meanly coarse silty } \\
\text { clayey soils on } \\
\text { loess-like subclay } \\
\end{array}$ & 3 & 124,95 & 10,83 & 102,73 & 1,66 & 41,65 & 0,98 & 5,06 & 1,33 & 2,42 & 1,29 \\
\hline 10 & $\begin{array}{l}\text { Chernozems } \\
\text { podzolized gleyish } \\
\text { weakly washed } \\
\text { meanly coarse silty } \\
\text { clayey soils on } \\
\text { loess-like subclay }\end{array}$ & 8 & 209,56 & 18,17 & 82,32 & 3,7 & 26,19 & 0,79 & 5,6 & 1,27 & 2,82 & 1,00 \\
\hline 11 & $\begin{array}{l}\text { Chernozems } \\
\text { podzolized gleyish } \\
\text { with spots of meanly } \\
\text { washed }(10-30 \%) \\
\text { meanly coarse silty } \\
\text { clayey soils on } \\
\text { loess-like subclay } \\
\end{array}$ & 1 & 18,44 & 1,60 & 18,44 & 18,44 & 18,44 & - & - & - & - & - \\
\hline 12 & $\begin{array}{l}\text { Chernozems } \\
\text { podzolized solodic } \\
\text { meanly coarse silty } \\
\text { clayey soils on } \\
\text { loess-like subclay }\end{array}$ & 1 & 22,04 & 1,91 & 22,04 & 22,04 & 22,04 & - & - & - & - & - \\
\hline 13 & $\begin{array}{l}\text { Meadow- } \\
\text { chornozemics water- } \\
\text { bearing washed } \\
\text { meanly coarse silty } \\
\text { clayey soils on } \\
\text { loess-like subclay }\end{array}$ & 6 & 24,07 & 2,09 & 8,65 & 0,75 & 4,01 & 0,73 & 4,96 & 1,48 & 3,11 & 0,41 \\
\hline 14 & $\begin{array}{l}\text { Meadow- } \\
\text { chornozemics water- } \\
\text { bearing washed } \\
\text { meanly coarse silty } \\
\text { clayey soils on } \\
\text { alluvium-deluvium } \\
\text { sediments }\end{array}$ & 2 & 12,05 & 1,04 & 7,06 & 4,99 & 6,02 & 0,17 & 1,36 & 1,31 & 1,34 & 0,24 \\
\hline 15 & $\begin{array}{l}\text { Meadow-boggy } \\
\text { washed soils on } \\
\text { alluvium-deluvium } \\
\text { sediments }\end{array}$ & 5 & 31,66 & 2,74 & 19,69 & 0,52 & 6,33 & 0,84 & 4,09 & 1,08 & 2,6 & 1,21 \\
\hline 16 & $\begin{array}{l}\text { Meadow-boggy } \\
\text { drained soils on } \\
\text { alluvium-deluvium } \\
\text { sediments }\end{array}$ & 1 & 44,23 & 3,83 & 44,23 & 44,23 & 44,23 & - & - & - & - & - \\
\hline
\end{tabular}


The ESA of azonal types of soils are distributed throughout the model area within the beams and ravines. All soils are formed on alluvial-deluvial sediments.

After analyzing the structure of the soil cover of the Olesha model area, the 47 ESA was recognized there. Within the model area, the following subtypes of grey forests soils were discovered. These are 3 areals of grey forests gleyish middle coarse soils, one areal of grey forests gleyish middle coarse weakly washed (30-50 \%), 3 areals of grey forests gley middle coarse weakly washed, and 4 areals of grey forests gleyish middle coarse meanly washed (10-30\%). All subtypes formed on loess-like subclay.

The size of the ESA of grey forests gleyish middle coarse soils varies from 5,63 to 45,45 hectares, the average area is 21,56 hectares. The degree of variability of the ESA areas was estimated using the coefficient of the differentiation of the soil outlines (CDSO) and the methods of variation statistics (coefficient of variation $-\mathrm{CV}$ ).

The area of the studied ESA is characterized by significant variability $(\mathrm{CDSO}=0,74$; $\mathrm{CV}=0,98)$. The shape, degree of sinuosity and elongation of the boundaries of the areals were estimated using the coefficient of the dismemberment (CD). According to the degree of dismemberment of the ESA, the grey forests gleyish middle coarse soils are classified as undifferentiated $($ Kser. $=1,67)$.

The areas of grey forests gleyish middle coarse eroded soils are less differentiated in size $\left(\mathrm{S}_{\min }=4,91\right.$ hectares; $\mathrm{S}_{\max }=14,33$ hectares; $\left.\mathrm{CDSO}=0,44\right)$; the average coefficient of disbursement is 1,75 , which relates these subtypes to the undisbursed, the variability of the coefficient of variation is negligible $-23,84 \%$, which may indicate a similarity of the areals shape. The size of ESA of grey forests gleyish middle coarse middle eroded soils is quite similar to the above-mentioned areals. Thus, their area varies in the range of 4,74 21,86 hectares, and CDSO is 0,5 , the degree of dismemberment - undisbursed, $\mathrm{CD}=1,39$ [Table 1]. The shape of most ESA of grey forests gleyish middle coarse eroded soils is elongated.

The dark-grey podzolized gleyish with spots of weakly washed (30-50 \%) meanly coarse silty clayey soils are characterized by a relatively moderate variability in size: from 29,77 to 95,8 hectares $(\mathrm{CV}=0,74)$. The coefficient of the differentiation of the soil outlines is 0,53 , which indicates a moderate deviation of the areas of the analyzed ESA from the mean value. The ESA contours of this soils are weakly divided (CDaver. $=2,81$ ), the coefficient of variation for the CD indicator is moderate, being 49,32\%. The dark-grey podzolized gleyish weakly washed meanly coarse silty clayey soils have a slight variability in the sizes $\left(\mathrm{S}_{\min }=12,85\right.$ hectares; $\mathrm{S}_{\max }=26,26$ hectares; $\left.\mathrm{CDSO}=0,23\right)$; they also have a low CD 2,02 and its low variability 0,33 [Table 1 ].

As mentioned above, the chernozems podzolized gleyish meanly coarse silty clayey soils within study area occupy a considerable area, more than $22 \%$ of the territory. They are characterized by a considerable variability in the area size - from 8,15 to 248,95 hectares $(\mathrm{V}=132,46)$. The shape of the ESA is predominantly asymmetric. According to the coefficient of the differentiation of the soil outlines these soils are characterized by the predominance of weakly separated contours. The value of the coefficient varies greatly $(1,39-3,23)$.

The chernozems podzolized gleyish weakly washed meanly coarse silty clayey soils are significantly distributed within study area. The dimensions of these ESA have large 
variation - from 1,66 to 102,73 hectares. The coefficient of the differentiation of the soil outlines and the coefficient of variation is significant $(\mathrm{CDSO}=0,79-0,98 ; \mathrm{CV}=0,99-1,29$ ). By the degree of dismemberment of the boundaries of the ESA, these soils are predominantly weakly divided (CDaver. $=2,42-2,82$ ). The ESA shapes of chernozems podzolized gleyish weakly washed meanly coarse silty clayey soils are quite varied - elongated, lobed, linear, asymmetric or symmetrical. The average area of the chornozems with spots of weakly washed soils is 41,65 hectares, and the weakly washed is almost two time less $-26,19$ hectares. This shows the general tendency to decrease the average area with the level of soils erosion. This pattern is also observed for the mean values of the average coefficient of disbursement (the chornozems with spots of weakly washed soils $-2,42$, the chornozems with weakly washed soils $-2,82$ ), what caused by increasing the sinuosity of the areals boundaries and increasing of the soils erosion degree.

The less areas are covered by chernozems podzolized gleyish meanly washed meanly coarse silty clayey soils and chernozems podzolized solodic meanly coarse silty clayey soils within Olesha model area. They are spread in the northern and northeastern part of the model area. Their total area is 40,48 hectares, which corresponds to only 3,51\% of the model area. The areals shape of these soils is elongated and lobed asymmetric.

In the hydromorphic conditions of the ravines and gullies of the Olesha study area the meadow-chornozemics water-bearing washed meanly coarse silty clayey soils and meadow-boggy washed soils were formed. The dimensions of the ESA are characterized by a significant variation $0,75-44,23$ hectares, the average coefficient of dismemberment varies widely from 1,34 to 6,36 . The vast majority of these areals are characterized by an elongated and asymmetric form. Among the meadowchornozemics water-bearing washed soils the minor-range areals are predominated $(0,75-$ 8,65 hectares). The degree of the coefficient of the differentiation of the soil outlines and the coefficient of variation are significant $(\mathrm{CDSO}=0,73 ; \mathrm{CV}=0,41 \%)$. Concerning the degree of dismemberment, the mediocre separated contours are dominated here (CDaver. $=3,11)$. The shape of the areals is considerably elongated. In the case of meadowchornozemics water-bearing washed soils, their average size varies slightly from 4,99 to 7,06 hectares, which is reflected to the low value of the coefficient of variability and the coefficient of the differentiation of the soil outlines $-0,41$ and 0,17 respectively. By the average value of the CD coefficient, these soils belong to the weakly separated (CDaver. $=1,34)$. The chernozem-meadow soils are characterized by a symmetrical, almost oval shape. Also, within model area, the six areals of meadow-bog soils have been identified. Their sizes vary in very wide limits $(0,52-44,23$ hectares $)$, the average coefficient of dismemberment is 2,6-6,36 and indicates on significant dismemberment of their contours, the coefficient of variability is significant - 1,21.

Conclusions. According to the existing classification, the ESA boundaries type can be sharply, clearly and not clearly defined. Studying the character of ESA boundaries of Olesha study area we found that for most of them characterized by clearly and not clearly defined. The clearly defined boundaries belong to the grey forests, dark-grey podzolized and chernozems podzolized, the not clearly defined borders - eroded soils. Sharply defined borders inherent to the various hydromorphic soils. To this type we can also include the boundaries between 
areas adjacent to the ravines and gullies: the boundaries between the chornozems podzolized and grey forests and chornozems podzolized and meadow-boggy soils etc.

What is the main ecological factors caused of the different types of ESA boundaries within Olesha model area? First of all, spatial distribution of rocks, the diversity of soil forming species (within the study area, the soils were formed on loess, or on alluvial-deluvial sediments), the change in moisture (almost all soils have different degrees of gley content), the development of erosion processes (the presence of ESA with varying erosion degree), extensive human economic activity.

To conclude, according to the national classification the soil cover formed with the smallest mapping units - elementary soil areal. These ESA form the micro and mesostructure of soil - microcombinations and mezostructures. The represented analyzed data and results of the field, cartographic and statistical analysis should be the basement for further evaluation of the higher levels of soil cover structure, e.g. soil combinations and soil cover in general.

\section{REFERENCES}

1. Has'kevych, O. V. (2004). The role of human factor in determining the structure of soil of Holohoro-Kremenets'koho Hill Ridge. Scientific notes of Ternopil' State Pedagogical University. Series Geography, 2, 138-143 (in Ukrainian).

2. Godelman, I. M. (1981). The heterogeneity of soil cover and land use. Moscow: Science, 202 pp. (in Russian).

3. Poznyak, S. P., Krasyekha, Y. N., \& Kit, M. H. (2003). Mapping of the soil cover. Lviv: Publishing center of Lviv Ivan Franko National University, 500 pp. (in Ukrainian).

4. Prasolov, L. I. (1978). Genesis, geography and soil cartography. Moscow: Science, 283 pp. (in Russian).

5. Radziy, V. F. (2000). Visnyk of the Lviv University. Series Geography, 26, 104-107 (in Ukrainian).

6. Radziy, V. F. (2009). The structure of the soil cover of Volyn' Upland. Luts'k: Publishing department "Vezha" Volyn National University of Lesya Ukrayinka, 206 pp. (in Ukrainian).

7. Stroganova, M. N. (n.d.). The structure of the soil cover and the soil mapping. Moscow. Retrieved February 6, 2016, from soil.msu.ru/kaf-geografia/1593-1177 (in Russian).

8. Fridland, V. M. (1986). Problems of geography, genesis and classification of the soils. Moscow: Science, 243 pp. (in Russian).

9. Fridland, V. M. (1973). The structure of the soil cover and the methods of its study. Moscow: Mysl, 257 pp. (in Russian).

\section{СПИСОК ВИКОРИСТАНОЇ ЛІТЕРАТУРИ}

1. Гаськевич $О$. В. Роль антропогенного чинника у формуванні структури грунтового покриву Гологоро-Кременецького горбогір'я // Наук. зап. Терн. держ. пед. ун-ту. Сер. Геогр. 2004. № 2. Ч. 1. С. 138-143.

2. Годельман Я. М. Неоднородность почвенного покрова и использование земель. Москва : Наука, 1981. 202 с.

3. Позняк С. П., Красєха С. Н., Кim М. Г. Картографування грунтового покриву. Львів : Видавничий центр ЛНУ імені Івана Франка. 2003. 500 с. 
4. Прасолов Л. И. Генезис, география и картография почв. Москва : Наука, 1978. 263 с.

5. Радзій $В . \Phi$. Генетико-геометрична будова структури грунтового покриву Волинської височини // Вісн. Львів. ун-ту. Сер. Геогр. 2000. Вип. 26. С. 104-107.

6. Радзій В. Ф., Позняк С. П. Структура грунтового покриву Волинської височини. Луцьк : Вежа, 2009. 206 с.

7. Строганова M. М. Структура почвенного покрова и почвенная картография. 2011. [Электронный ресурс]. Режим доступа : http://soil.msu.ru/kaf-geografia/1593-1177.

8. Фридланд В. М. Проблемы географии, генезиса и классификации почв. Москва : Наука, 1986. 243 с.

9. Фридланд В. М. Структура почвенного покрова и методы ее изучения. Москва : Мысль, 1973. 257 с.

Стаття: надійшла до редакиії 10.10. 2017 доопрачьована 10.11. 2017 прийнята до друку 15.12. 2017

\title{
СТРУКТУРА ГРУНТОВОГО ПОКРИВУ ТА ЕЛЕМЕНТАРНІ ІРУНТОВІ АРЕАЛИ ОПІЛЛЯ
}

\author{
Тарас Ямелинець, Микола Федотіков
}

\author{
Львівський національний університет імені Івана Франка, \\ вул. П. Дорошенка, 41, м. Львів, 79007, Україна, \\ e-mail:taras.yamelynets@gmail.com
}

Для вивчення структури грунтового покриву Опілля використано методи виявлення (натурно-картометричний, пластики рельєфу, якісно-генетичний) та інтерпретації (статистикокартометричний, функціонально-аналітичний) структури грунтового покриву. Зокрема, для характеристики елементарних грунтових ареалів модельної ділянки використано натурнокартометричний метод, що дає змогу визначити параметри структури грунтового покриву й отримати кількісні показники для основних параметрів, якими $є$ склад та співвідношення площ елементарних грунтових ареалів, складність, дрібність, розчленування, контрастність і неоднорідність.

Наведено результати вивчення якісних та кількісних характеристик елементарних грунтових ареалів Ходорівсько-Бучацького Опілля на прикладі Олешівської модельної ділянки. За допомогою коефіцієнта ступеня диференціації грунтових контурів та методів варіаційної статистики визначено й проаналізовано ступінь мінливості площ елементарних грунтових ареалів. Досліджено форму, ступінь звивистості та витягнутості меж ареалів за допомогою коефіцієнта розчленування. Вивчено характер меж елементарних грунтових ареалів на території дослідження. Виявлено основні особливості залежності меж цих ареалів від різних екологічних чинників. Простежено певні закономірності зміни основних параметрів елементарних грунтових ареалів, що формують структуру грунтового покриву Ходорівсько-Бучацького Опілля.

Ключові слова: елементарний грунтовий ареал (ЕГА), структура грунтового покриву (СГП), ступінь диференціації грунтових контурів (СДІК), коефіцієнт розчленування (КР) меж ареалів, коефіцієнт варіабельності (V). 